\title{
EFEKTIVITAS KRIM EKSTRAK METANOL BATANG DAN DAUN PACAR AIR (Impatiens balsamina L.) TERHADAP BAKTERI Propionibacterium acnes
}

\author{
Wendy, Liza Pratiwi, Indri Kusharyanti \\ Program Studi Farmasi Fakultas Kedokteran, Universitas Tanjungpura, Pontianak \\ Jalan Prof. Dr. H. Hadari Nawawi Pontianak
}

\begin{abstract}
Colonization of Propionibacterium acnes is one of factors that causes acne vulgaris. The present study was conducted to evaluate antiacne effect from cream of methanolic extract from stems and leaves of Impatiens balsamina L. towards Propionibacterium acnes, concentration that gives greatest antiacne effect and to evaluate physical and chemical properties of creams. Simplicia were extracted using soxhlet technique and methanol as solvent. Extract then formulated in cream in three variations of concentration as following $10 \%(F 1), 15 \%(F 2)$ and $20 \%(F 3)$. The determination of antiacne effect was done using disc diffusion method. Evaluation of physical and chemical properties of those creams includes organoleptic examination, spreadability, adhesion and $\mathrm{pH}$ testing. Data were analyzed using $R$ version 2.14.1 package $R$-commander. Determination results showed the diameter

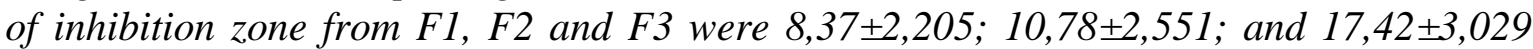
$\mathrm{mm}$ respectively. Analysis results showed that cream of $\mathrm{F3}$ gave significantly greatest antiacne effect compared to $F 1$ and $F 2$ ( $p<0,05)$, and not significantly different to the positive control $(p>0,05)$. The evaluation of creams showed that they had homogenous texture, nongreasy, easily washed, spreadability of 10,18 $\pm 0,285$ to $11,55 \pm 0,687 \mathrm{~cm}^{2}$, adhesion force of 33,299 $\pm 2,821$ to $60 \pm 0$ minutes, and $p H$ of 6,07 $\pm 0,058$ to 6,37 $\pm 0,115$, this showed that creams have good physical and chemical properties.
\end{abstract}

Keywords: Antiacne, Impatiens balsamina L. stems and leaves extract, Propionibacterium acnes

\begin{abstract}
ABSTRAK
Kolonisasi bakteri Propionibacterium acnes merupakan salah satu penyebab terjadinya jerawat. Penelitian ini dilakukan untuk mengetahui efek antijerawat krim ekstrak metanol batang dan daun pacar air (Impatiens balsamina L.) terhadap bakteri Propionibacterium acnes, mengetahui konsentrasi krim yang memberikan efek antijerawat yang paling besar serta mengevaluasi sifat fisik dan kimia krim. Simplisia disokletasi menggunakan pelarut metanol. Ekstrak diformulasikan ke dalam sediaan krim dengan variasi konsentrasi ekstrak yaitu 10\%(F1), 15\%(F2) dan 20\%(F3). Pengujian efektivitas krim dilakukan dengan metode difusi cakram. Evaluasi sifat fisik dan kimia sediaan krim yang dilakukan meliputi pemeriksaan organoleptis, pengujian daya sebar, daya lekat dan $\mathrm{pH}$. Analisis data menggunakan program R seri 2.14.1 modul R-commander. Hasil penelitian menunjukkan daya hambat krim F1, F2 dan F3 terhadap bakteri masing-masing sebesar 8,37 $\pm 2,205$; $10,78 \pm 2,551$; dan 17,42 $\pm 3,029 \mathrm{~mm}$. Hasil analisis menunjukkan bahwa F3 memberikan efek antijerawat yang paling besar dan berbeda signifikan dibandingkan dengan F1 dan F2 $(\mathrm{p}<0,05)$ serta tidak berbeda signifikan dibandingkan dengan kontrol positif $(\mathrm{p}>0,05)$. Hasil evaluasi menunjukkan sediaan homogen, tidak berminyak, mudah tercuci, memiliki

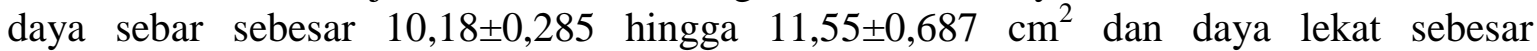




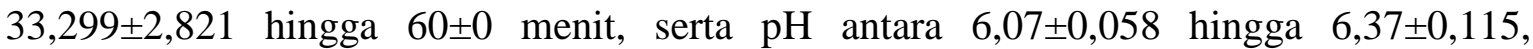
menunjukkan bahwa sediaan memiliki sifat fisik dan kimia yang baik.

Kata kunci: Antijerawat, ekstrak batang dan daun pacar air, Propionibacterium acnes

\section{PENDAHULUAN}

Jerawat merupakan penyakit kulit kronis yang dapat terjadi pada semua usia, dari neonatus hingga dewasa, namun prevalensi paling sering ialah pada masa remaja, puncaknya pada usia 14-17 tahun pada perempuan dan 16-19 tahun pada laki-laki $(1,2)$. Empat faktor utama penyebab jerawat antara lain peningkatan produksi sebum, hiperkeratinisasi folikular, kolonisasi bakteri Propionibacterium acnes dan terjadinya inflamasi (3).

Pemilihan terapi untuk jerawat disesuaikan dengan tingkat keparahan dan perluasan dari penyakit (4). Obat OTC (over the counter) maupun obat resep, terutama sediaan topikal yang mengandung retinoid; benzoil peroksida; antibiotik; asam salisilat; asam azaleat; dan nikotinamid, merupakan terapi yang diperlukan untuk jerawat ringan dan menengah $(5,6)$. Sedangkan untuk jerawat yang parah di mana terjadi inflamasi dan resistensi terhadap sediaan topikal, digunakan sediaan oral (7). Penggunaan obat-obat ini juga dapat menyebabkan efek samping dan bahkan terjadi resistensi pada antibiotik yang sering digunakan (8). Studi terhadap isolat bakteri $P$. acnes di Inggris menemukan bahwa resistensinya terhadap eritromisin dan klindamisin meningkat dari 35\% pada tahun 1991 menjadi 55\% pada tahun 2000 (9).

Terjadinya

resistensi menyebabkan kegagalan dari terapi. Pengobatan alternatif terhadap jerawat telah diteliti dan dikembangkan, yaitu menggunakan bahan alam dalam mengobati jerawat (10). Salah satu tanaman yang saat ini dapat dimanfaatkan sebagai antibakteri yaitu tanaman pacar air (Impatiens balsamina L.). Penelitian yang telah dilakukan menunjukkan bahwa ekstrak pacar air memberikan efek antibakteri terhadap Propionibacterium acnes, di mana senyawa yang berperan dalam aktivitas antibakteri adalah flavonoid dan naftokuinon (11). Aktivitas antibakteri yang baik dari tanaman pacar air menunjukkan potensinya untuk digunakan sebagai antijerawat.

Salah satu bentuk sediaan yang dapat dipilih ialah krim. Sediaan krim dipilih karena merupakan sistem emulsi yang mudah dioleskan dengan tekstur yang lembut dan dapat digunakan pada bagian kulit yang luas. Krim tipe M/A bersifat tidak berminyak, mudah menyebar pada kulit dan memberikan rasa dingin pada lokasi aplikasi krim. Sedangkan krim tipe A/M kurang disukai secara kosmetik dan estetik karena dapat memberikan rasa berminyak dan sensitisasi saat penggunaan (12). Krim tipe M/A bila digunakan pada kulit, fase luar akan menguap dan dapat meningkatkan konsentrasi obat yang larut dalam air pada lapisan film yang melekat/tertinggal. Gradien konsentrasi obat yang menembus kulit juga meningkat (karena konsentrasi pada lapisan kulit meningkat), sehingga dapat meningkatkan absorpsi perkutan (13).

Berdasarkan uraian di atas, maka dilakukan pengujian efektivitas antijerawat krim ekstrak metanol batang dan daun pacar air terhadap bakteri penyebab jerawat yaitu Propionibacterium acnes, serta mengetahui sifat fisik dan kimia dari krim yang dihasilkan.

\section{METODE PENELITIAN}


9410-003), waterbath (Memmert tipe WNB-14), blender simplisia, vacuum rotary evaporator (Heldolph tipe Basis Hei-VAP Value), alat-alat gelas, mikropipet, hot plate (SCHOTT tipe D55122 Mainz), krusibel porselen, laminar air flow cabinet, autoklaf (HL tipe 36Ae), object glass, cover glass, kaca arloji, mantel pemanas (Toshniwal tipe HM. 0500), pH meter (Horiba tipe D-51), oven (Memmert Beschickung-Loading Model 100-800), desikator, cawan penguap, mortir, stamper, jarum ose, inkubator, lampu Bunsen, cawan petri, dan jangka sorong.

\section{Bahan}

Bahan-bahan yang digunakan dalam penelitian ini meliputi bahan tumbuhan, bahan kimia dan bakteri uji. Bahan tumbuhan yang digunakan adalah simplisia batang dan daun pacar air (Impatiens balsamina L.). Bahan kimia yang digunakan meliputi bahan kualitas teknis dan pro analisis. Bahan kualitas teknis yang digunakan adalah kertas saring, kertas saring Whatman no. 1, krim Zeliris ${ }^{\circledR}$ metanol, pereaksi Mayer, pereaksi Dragendorff, Besi (III) klorida $\left(\mathrm{FeCl}_{3}\right) 5 \%$,ammonia $1 \%$, asam asetat anhidrida,larutan Kalium hidroksida $(\mathrm{KOH}) \quad 5 \%$,larutan Natrium klorida $(\mathrm{NaCl}) 0,9 \%$, asam stearat (PT. Brataco, Batch B130419-13), setil alkohol (PT. Brataco, Batch 1012060401), TEA, gliserin (PT. Brataco, Batch 1K2119203), metil paraben (Ueno Fine Chemicals Industry), akuabides dan akuades. Bahan kualitas pro analisis yang digunakan antara lain media Mueller-Hilton Agar (MHA), darah kambing steril, Dimetil sulfoksida (DMSO), Magnesium (Mg), asam klorida $(\mathrm{HCl})$ pekat, asam sulfat $\left(\mathrm{H}_{2} \mathrm{SO}_{4}\right)$ pekat, kloroform $\left(\mathrm{CHCl}_{3}\right)$, larutan standar McFarland no 0,5.Bakteri uji yang digunakan pada penelitian ini adalah kultur bakteri Propionibacterium acnes yang merupakan koleksi dari unit Laboratorium Mikrobiologi Fakultas Kedokteran Universitas Indonesia.

\section{Tahapan Penelitian}

\section{Sampel}

Sampel yang digunakan pada penelitian ini adalah batang dan daun pacar air yang diperoleh di Jl. Nirbaya, Kota Baru, Pontianak, Kalimantan Barat. Sampel yang diperoleh dideterminasi di Herbarium Bogoriense, Bidang Botani Pusat Penelitian Biologi-LIPI Bogor. Sampel kemudian dibuat menjadi simplisia dan disokletasi menggunakan pelarut metanol.

\section{Skrining Fitokimia}

Skrining fitokimia dilakukan terhadap ekstrak metanol batang dan daun pacar air meliputi pemeriksaan alkaloid, flavonoid, polifenol, tanin, triterpenoid, steroid, saponin dan kuinon.

\section{Uji Aktivitas Antibakteri Ekstrak}

Uji aktivitas antibakteri dari ekstrak metanol batang dan daun pacar air dilakukan dengan metode disc diffusion. Larutan ekstrak terdiri dari tiga variasi konsentrasi: $100 \mathrm{mg} / \mathrm{mL} ; 150$ $\mathrm{mg} / \mathrm{mL}$; dan $200 \mathrm{mg} / \mathrm{mL}$. Kontrol negatif yang digunakan adalah DMSO. Sebanyak $20 \mu \mathrm{L}$ larutan ekstrak dan kontrol negatif dipipet ke kertas cakram. Kertas cakram kemudian diletakkan pada permukaan media Mueller-Hilton Agar (MHA) dengan 5\% darah kambing yang telah diinokulasikan bakteri $P$. acnes. Petri diinkubasi pada suhu $37^{\circ} \mathrm{C}$ selama 48 jam. Pengujian dilakukan 3 kali pengulangan (14).

\section{Formulasi Krim}

Formulasi

krim dibuat berdasarkan formula pada tabel 1. Bahanbahan fase minyak (asam stearat dan setil alkohol) dan fase air (TEA, gliserin, metil paraben dan air) dipisahkan. Fase minyak dan fase air dipanaskan hinga suhu $70^{\circ} \mathrm{C}-$ $80^{\circ} \mathrm{C}$. Setelah semuanya melebur, dimasukkan fase air sedikit demi sedikit ke dalam lumpang panas yang berisi fase minyak. Dimasukkan ekstrak batang dan 
daun pacar air ke dalam mortar, dicampur dengan basis krim sedikit demi sedikit hingga didapatkan massa krim yang homogen.

\section{Uji Efek Antijerawat Krim}

Uji aktivitas antibakteri dari krim ekstrak metanol batang dan daun pacar air dilakukan dengan metode disc diffusion. Kertas cakram direndam dalam krim F1, F2, F3, kontrol positif dan kontrol negatif. Kertas cakram kemudian diletakkan pada permukaan media Mueller-Hinton Agar (MHA) dengan 5\% darah kambing pada petri yang telah diinokulasikan bakteri $P$. acnes. Petri dibiarkan pada suhu ruang selama 1 jam sebelum diinkubasi pada suhu $37^{\circ} \mathrm{C}$ selama 48 jam. Aktivitas antibakteri ditentukan dengan mengukur diameter zona hambat. Untuk kontrol positif digunakan krim Zeliris. Pengujian dilakukan 3 kali pengulangan (14).

Tabel 1. Formula Krim Ekstrak Batang dan Daun Pacar Air

\begin{tabular}{cccc}
\hline Bahan & F1 & F2 & F3 \\
\hline Ekstrak & 10 & 15 & 20 \\
Asam Stearat & 12 & 12 & 12 \\
Setil Alkohol & 2 & 2 & 2 \\
TEA & 3 & 3 & 3 \\
Gliserin & 8 & 8 & 8 \\
Metil Paraben & 0,2 & 0,2 & 0,2 \\
Akuades ad & 100 & 100 & 100 \\
\hline
\end{tabular}

Keterangan:

$\mathrm{F} 1=$ Formula krim dengan ekstrak konsentrasi $10 \%$;

$\mathrm{F} 2=$ Formula krim dengan ekstrak konsentrasi $15 \%$;

$\mathrm{F} 3=$ Formula krim dengan ekstrak konsentrasi $20 \%$.

\section{Evaluasi Sediaan Krim}

Evaluasi sediaan krim yang dilakukan meliputi pengamatan organoleptis, pengukuran $\mathrm{pH}$, pengujian daya sebar dan pengujian daya lekat.

\section{Pengamatan Organoleptis}

Pemeriksaan organoleptis yang dilakukan meliputi pemeriksaan bentuk, tekstur, warna dan bau yang diamati secara visual (15).

\section{Pengukuran pH}

Pengukuran $\mathrm{pH}$ sediaan dilakukan dengan menggunakan $\mathrm{pH}$ meter soil tester. Alat $\mathrm{pH}$ meter dicelupkan secara langsung ke dalam sediaan krim. Kemudian dilihat perbahan skala pada $\mathrm{pH}$ meter. Angka yang tertera pada skala $\mathrm{pH}$ meter merupakan nilai $\mathrm{pH}$ dari sediaan.

\section{Pengujian Daya Sebar}

Krim sebanyak 0,5 g diletakkan di tengah-tengah kaca bulat, ditutup dengan kaca lain yang telah ditimbang beratnya dan dibiarkan selama 1 menit kemudian diukur diameter sebar krim. Setelah itu ditambahkan beban $50 \mathrm{~g}$ dan dibiarkan 1 menit kemudian diukur diameter sebarnya. Penambahan beban berat setelah 1 menit dilakukan secara terusmenerus hingga diperoleh diameter yang cukup untuk melihat pengaruh beban terhadap perubahan diameter sebar krim (16).

\section{Pengujian Daya Lekat}

Krim sebanyak 0,25 g diletakkan pada gelas obyek dan ditekan dengan beban $1 \mathrm{~kg}$ selama 5 menit. Setelah itu gelas obyek dipasang pada alat tes. Alat tes diberi beban $80 \mathrm{~g}$ dan kemudian dicatat waktu pelepasan krim dari gelas obyek (16).

\section{Analisis Data}

Data kuantitatif yang diperoleh meliputi diameter zona hambat ekstrak dan krim, pH krim, daya sebar dan daya lekat krim. Analisis data dilakukan dengan menggunakan program $\mathrm{R}$ seri 2.14.1. modul R-commander. Uji normalitas data dilakukan dengan uji Saphiro-Wilk. Uji homogenitas data dilakukan dengan uji Levene's Test of Homogenity of Variance. Data kemudian 
dianalisis dengan One Way ANOVA (Analysis of Varians) untuk membandingkan nilai signifikansi diameter zona hambat dari ekstrak konsentrasi I, II, III; formula I, II dan III; kontrol positif dan kontrol negatif.

\section{HASIL DAN PEMBAHASAN}

\section{Determinasi Sampel Tumbuhan}

Berdasarkan hasil identifikasi tanaman yang dilakukan di Herbarium Bogoriense, Bidang Botani Pusat
Penelitian Biologi-LIPI Bogor menyatakan bahwa tanaman yang digunakan pada penelitian ini adalah tanaman pacar air dengan spesies Impatiens balsamina $\mathrm{L}$.

\section{Skrining Fitokimia}

Hasil skrining fitokimia terhadap ekstrak metanol batang dan daun pacar air ditunjukkan pada tabel 2. Hasil menunjukkan ekstrak mengandung senyawa flavonoid, kuinon dan polifenol.

Tabel 2. Hasil Uji Skrining Fitokimia Ekstrak Batang dan Daun Pacar Air

\begin{tabular}{cccc}
\hline No. & Pemeriksaan & Reagen & Hasil \\
\hline 1. & Alkaloid & Mayer, Dragendorf & - \\
2. & Flavonoid & Mg + HCl pekat & + \\
3. & Saponin & Akuades & - \\
4. & Tanin & NaCl, Gelatin & - \\
5. & Triterpenoid & Lieberman Burchard & - \\
6. & Steroid & Lieberman Burchard & - \\
7. & Naftokuinon & KOH 5\% & + \\
8. & Polifenol & FeCl3 & + \\
\hline
\end{tabular}

Keterangan : $(+)=$ mengandung senyawa yang diuji;

$(-)=$ tidak mengandung senyawa yang diuji.

Tabel 3. Hasil Pengujian Aktivitas Antibakteri Ekstrak ( $\bar{x} \pm \mathrm{SD}, \mathrm{n}=3)$

\begin{tabular}{ccc}
\hline No. & Konsentrasi ekstrak $(\mathrm{mg} / \mathrm{mL})$ & Diameter Zona Hambat $(\mathrm{mm})$ \\
\hline 1. & 100 & $8,517 \pm 0,289$ \\
2. & 150 & $10,050 \pm 0,652$ \\
3. & 200 & $9,833 \pm 0,752$ \\
4. & $\mathrm{~K}(-)$ DMSO $10 \%$ & - \\
\hline
\end{tabular}

Keterangan : $\mathrm{n}=$ jumlah data;

$\mathrm{SD}=$ Standar Deviasi ;

$\bar{x}=$ nilai rata-rata.

\section{Hasil Uji Aktivitas Antibakteri Ekstrak}

Uji aktivitas aktibakteri dilakukan dengan metode disc diffusion. Metode disc diffusion adalah metode untuk menentukan aktivitas suatu agen antimikroba. Kontrol negatif yang digunakan ialah larutan DMSO, karena DMSO tidak memberikan aktivitas antibakteri terhadap bakteri $P$. acnes ${ }^{(17)}$.

Hasil uji aktivitas antibakteri (tabel 3) dari kontrol negatif tidak menunjukkan adanya zona hambat. Aktivitas tertinggi ditunjukkan oleh larutan ekstrak dengan konsentrasi 150 $\mathrm{mg} / \mathrm{mL}$ dan aktivitas terendah oleh larutan ekstrak konsentrasi $100 \mathrm{mg} / \mathrm{mL}$. Hasil pengujian menunjukkan bahwa ekstrak metanol batang dan daun pacar air memiliki aktivitas antibakteri terhadap bakteri penyebab jerawat yaitu bakteri $P$. acnes. Bakteri $P$. acnes yang merupakan bakteri Gram positif memiliki susunan membran sel yang relatif sederhana yaitu 
hanya terdiri dari peptidoglikan dan asam teiakoat yang bersifat sangat polar sehingga senyawa dalam ekstrak yang bersifat polar mudah menembus membran.

Senyawa yang diduga berperan sebagai antibakteri ialah senyawa golongan flavonoid dan naftokuinon. Senyawa flavonoid yang terkandung dalam tanaman pacar air yang telah diketahui memiliki aktivitas antibakteri terhadap bakteri $P$. acnes ialah senyawa kaemferol dan kuersetin. Sedangkan senyawa naftokuinon yang memiliki aktivitas antibakteri ialah senyawa 2hidroksi 1,4-naftokuinon, 2-metoksi 1,4naftokuinon dan metilen 3,3'-bilawsone. Kuersetin memiliki aktivitas antibakteri yaitu dengan menghambat DNA-gyrase dari bakteri, selain itu juga kuersetin dapat meningkatkan permeabilitas dari membran sel bakteri dan menghilangkan potensial membran sel bakteri yang mana gradien elektrokimia dari proton yangmelewati membran ini penting bagi bakteri untuk sintesis ATP, transpor membran dan motilitas. Kaemferol diduga memiliki aktivitas yang sama dengan kuersetin karena memiliki struktur yang hampir sama dan juga memiliki konsentrasi hambat minimal yang sama dengan kuersetin terhadap bakteri $P$. acnes (18). Naftokuinon memiliki aktivitas antibakteri yaitu dengan mekanisme mengikat asam amino nukleofilik dari protein secara irreversible yang sering kali menyebabkan inaktifasi dari protein dan kehilangan fungsi. Selain itu naftokuinon juga mengikat adhesin, polipeptida dari dinding sel dan enzim pada membran ${ }^{(19)}$. Analisis perbandingan aktivitas antibakteri dari ketiga konsentrasi ekstrak dilakukan dan hasilnya menunjukkan bahwa aktivitas antibakteri dari ketiga konsentrasi ekstrak tidak menunjukkan perbedaan yang signifikan. Hal ini ditunjukkan dari nilai $\mathrm{p}>0,05$.

Tabel 4. Hasil Pengujian Aktivitas Antibakteri Krim $(\bar{x} \pm S D, n=3)$

\begin{tabular}{ccc}
\hline No. & Formula & Diameter zona hambat $(\mathrm{mm})$ \\
\hline 1. & F1 & $8,37 \pm 2,205$ \\
2. & F2 & $10,78 \pm 2,551$ \\
3. & F3 & $17,42 \pm 3,029$ \\
4. & Kontrol Positif & $15,43 \pm 2,200$ \\
5. & Kontrol Negatif & 0 \\
\hline
\end{tabular}

Keterangan : $\mathrm{F} 1=$ Formula krim konsentrasi $10 \%$, $\mathrm{F} 2=$ Formula krim konsentrasi $15 \%$, F3 = Formula krim konsentrasi $20 \%$.

Hasil Uji Efek Antijerawat Krim

Krim yang dibuat dalam penelitian ini terdiri dari tiga krim dengan variasi konsentrasi ekstrak, yaitu $10 \%$, $15 \%$ dan $20 \%$. Ketiga formula krim tersebut diuji aktivitas antibakterinya terhadap bakteri $P$. acnes serta dibandingkan dengan kontrol negatif berupa basis krim serta dibandingkan dengan kontrol positif krim Zeliris. Hasil uji efektivitas antibakteri sediaan krim dapat dilihat pada tabel 4 .

Analisis efektivitas antibakteri sediaan dilakukan untuk melihat perbedaan antar formula, serta membandingkan efektivitas sediaan dengan kontrol positif. Hasil analisis menunjukkan bahwa antara F1 dan F2 memberikan zona hambat yang tidak berbeda signifikan. Sedangkan F3 saat dibandingkan dengan $\mathrm{F} 1$ dan $\mathrm{F} 2$ memperlihatkan hasil yang berbeda signifikan dilihat dari nilai $\mathrm{p}<0,05$, namun tidak berbeda signifikan terhadap kontrol positif yang digunakan. Berdasarkan data analisis tersebut dapat disimpulkan efektivitas antibakteri sediaan krim yang paling baik adalah 
krim F3.Analisis data terhadap aktivitas antibakteri larutan ekstrak dan sediaan krim dilakukan untuk melihat ada atau tidaknya pengaruh pembuatan sediaan krim terhadap aktivitas antibakteri yang dihasilkan. Hasil analisis memperlihatkan bahwa pada konsentrasi $10 \%$ dan $15 \%$, antara ekstrak dengan sediaan krim tidak menunjukkan perbedaan yang signifikan dalam hal zona hambat yang dihasilkan meskipun terjadi peningkatan aktivitas antibakteri pada sediaan krim. Sedangkan ekstrak konsentrasi 20\% yang dibuat dalam sediaan krim menunjukkan peningkatan aktivitas antibakteri yang signifikan berbeda dilihat dari nilai $\mathrm{p}<0,05$ (tabel 5).

Tabel 5. Hasil Analisis Independent Sample T-Test Aktivitas Antibakteri antar Ekstrak dengan Krim

\begin{tabular}{cccc}
\hline No. & Pasangan Kelompok & Nilai Signifikansi & Keterangan \\
\hline 1. & A1 - F1 & $\mathrm{p}>0,05$ & Tidak berbeda signifikan \\
2. & A2 - F2 & $\mathrm{p}>0,05$ & Tidak berbeda signifikan \\
3. & A3 - F3 & $\mathrm{p}<0,05$ & Berbeda signifikan \\
\hline
\end{tabular}

Keterangan: $\quad$ A1 = Larutan ekstrak konsentrasi $100 \mathrm{mg} / \mathrm{mL}$;

$\mathrm{F} 1=$ Formula krim konsentrasi $10 \%$

A1 = Larutan ekstrak konsentrasi $150 \mathrm{mg} / \mathrm{mL}$;

F2 = Formula krim konsentrasi $15 \%$

A1 = Larutan ekstrak konsentrasi $200 \mathrm{mg} / \mathrm{mL}$;

F3 = Formula krim konsentrasi $20 \%$

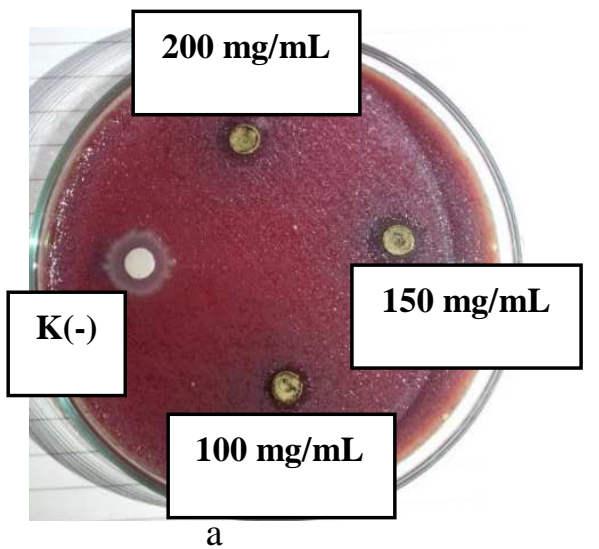

Gambar 1. Hasil Uji Aktivitas Antibakteri Ekstrak (a) dan Krim (b) terhadap Bakteri Propionibacterium acnes

Formulasi sediaan krim memberikan peranan yang penting dalam meningkatkan aktivitas antibakteri. Hal ini dilihat dari hasil pengujian ekstrak tidak menunjukkan peningkatan aktivitas yang signifikan seiring dengan kenaikan dosis ekstrak. Namun saat diformulasikan ke dalam sediaan krim, terjadi peningkatan aktivitas seiring dengan kenaikan dosis ekstrak dalam sediaan. Sifat krim yang tersusun atas dua fase

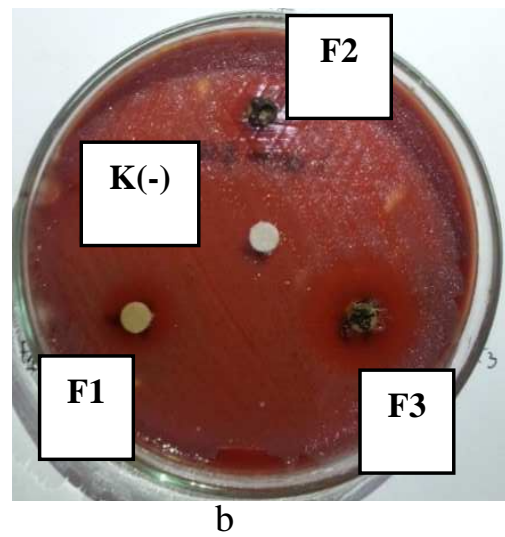

yang tidak saling campur mirip dengan sifat alami kulit, sehingga ekstrak yang diformulasikan sebagai krim dapat lebih efektif berinteraksi dengan kulit dan berpenetrasi ke dalam kulit ${ }^{(20)}$. Formulasi krim dapat meningkatkan kelarutan dari zat aktif dan meningkatkan permeabilitasnya pada kulit. Hal ini terjadi karena terjadinya interaksi peran yang kompleks antara zat aktif, pembawa dan barier kulit ${ }^{(21)}$. Sifat rheologi yaitu 
viskositas dari sediaan semipadat seperti krim dapat mempengaruhi penghantaran zat aktif (22). Menurut penelitian Swastika, dkk terhadap krim ekstrak sari tomat (Solanum lycopersicum L.), viskositas dari sediaan krim dapat dipengaruhi oleh konsentrasi ekstrak yang terkandung di dalam krim ${ }^{(23)}$. Secara umum, peningkatan dari viskositas dapat menyebabkan struktur pembawa menjadi lebih rigid dan kecepatan pelepasan obat menjadi menurun ${ }^{(24)}$.

Penetrasi zat aktif ke dalam kulit juga meningkat dengan keberadaan surfaktan. Surfaktan merupakan enhancer yang bekerja dengan mengganggu lapisan barier lipid pada epidermis dan meningkatkan partisi dari zat aktif. Surfaktan yang masuk ke dalam lapisan lipid bilayer membentuk saluran sehingga meningkatkan permeabilitas dari stratum korneum. Surfaktan dapat meningkatkan partisi zat aktif dengan cara mengganggu sifat kelarutan dari jaringan sehingga zat aktif yang dapat masuk ke dalam membran meningkat ${ }^{(24)}$.

Tabel 6. Hasil Pengamatan Organoleptis

\begin{tabular}{|c|c|c|c|}
\hline \multirow{2}{*}{ Uji } & \multicolumn{3}{|c|}{ Hasil Pengamatan } \\
\hline & F1 & $\mathrm{F} 2$ & $\mathrm{~F} 3$ \\
\hline Warna & Hijau & Hijau tua & Hijau tua \\
\hline $\mathrm{Bau}$ & Khas & Khas & Khas \\
\hline Bentuk & Krim kental, homogen & Krim kental, homogen & Krim kental, homogen \\
\hline Tekstur & $\begin{array}{ll}\text { Lembut, } & \text { tidak } \\
\text { berminyak dan mudah } \\
\text { tercuci }\end{array}$ & $\begin{array}{l}\text { Lembut, tidak berminyak } \\
\text { dan mudah tercuci }\end{array}$ & $\begin{array}{l}\text { Lembut, tidak berminyak } \\
\text { dan mudah tercuci }\end{array}$ \\
\hline
\end{tabular}

\section{Hasil Evaluasi Sediaan Krim}

\section{Pengamatan Organoleptis}

Pengamatan organoleptis dilakukan terhadap sediaan krim dilakukan pada tiga formula: F1, F2 dan F3 dengan melihat bentuk, tekstur, warna dan bau dari krim secara visual. Hasil pengamatan organoleptis dapat dilihat pada tabel 6 . Dari hasil pengamatan, didapat bahwa ketiga formula memiliki bentuk dan konsistensi yang mirip yakni bentuk krim kental yang homogen, dilihat dari sediaan krim tidak memperlihatkan adanya butir-butir kasar pada saat sediaan dioleskan pada kaca transparan. Ketiga formula juga memiliki tekstur yang lembut, tidak berminyak dan mudah tercuci. Hal ini penting karena krim yang baik harus homogen, tidak berminyak dan mudah dicuci. Dari segi warna, ketiga formula memiliki warna hijau di mana pada F2 dan F3 memperlihatkan warna hijau yang lebih gelap. Sedangkan aroma atau bau yang dimiliki krim ialah bau khas ekstrak dari pacar air.

\section{Pengukuran pH}

Pengukuran $\mathrm{pH}$ sediaan krim dilakukan terhadap tiga formula: F1, F2 dan $\mathrm{F} 3$ dengan menggunakan $\mathrm{pH}$ meter (soil tester). Nilai $\mathrm{pH}$ sediaan yang dihasilkan yaitu $6,37 \pm 0,115$ untuk F1 dan F2, serta 6,07 $\pm 0,058$ untuk F3. Nilai $\mathrm{pH}$ sediaan F1 dan F2 memperlihatkan $\mathrm{pH}$ rata-rata yang sama, sedangkan $\mathrm{pH}$ sediaan F3 menunjukkan penurunan, hal ini disebabkan oleh tingginya konsentrasi ekstrak yang dapat mempengaruhi $\mathrm{pH}$ dari sediaan krim. Akan tetapi pH yang dimiliki oleh ketiga sediaan masih berada dalam rentang $\mathrm{pH}$ sediaan yang ideal yaitu 4,5 - 6,5 di mana nilai ini masuk dalam rentang $\mathrm{pH}$ kulit sehingga dapat menghindari resiko iritasi setelah pemakaian pada kulit ${ }^{(25,26)}$.

\section{Pengujian Daya Sebar}

Pengamatan daya sebar bertujuan untuk melihat kemampuan krim untuk dapat menyebar pada permukaan kulit 
sehingga dapat diketahui penyebaran zat aktif yang dikandung oleh krim yang telah dibuat. Hasil pengujian daya sebar memperlihatkan pelebaran daya sebar seiring dengan meningkatnya konsentrasi ekstrak dalam krim. Daya sebar ini juga berhubungan dengan kekentalan dari krim yang dapat dijelaskan dengan semakin tinggi kekentalan yang dimiliki, daya sebar akan semakin kecil. Sediaan F1 memiliki kekentalan yang paling tinggi dan daya sebar yang paling kecil yaitu sebesar 10,18 $\pm 0,285$, sedangkan sediaan F3 memiliki kekentalan yang paling rendah dan daya sebar yang paling besar yaitu sebesar 11,55 $\pm 0,687$.

\section{Pengujian Daya Lekat}

Pengujian daya lekat dilakukan untuk mengetahui kemampuan sediaan krim bertahan di permukaan kulit ketika dioleskan. Semakin besar nilai daya lekat maka semakin besar difusi obat karena ikatan yang terjadi antara krim dengan kulit semakin lama. Berdasarkan hasil pengujian, sediaan F1 (>60 menit) memberikan daya lekat paling lama dibandingkan F2 (43,199 $\pm 2,340$ menit) dan F3 (33,299 $\pm 2,821$ menit). Hal ini disebabkan konsistensi sediaan F1 yang lebih kental, maka gaya antar atom pada sediaan lebih kuat dibandingkan sediaan F2 dan F3 sehingga sediaan dapat melekat lebih lama ${ }^{(27)}$.

Krim yang memberikan efek antijerawat paling besar terhadap $P$. acnes ialah krim F3 yang mengandung ekstrak dengan konsentrasi 20\%. Hal ini ditunjukkan dengan aktivitas antibakteri yang paling besar dan sama efektifnya dibandingkan dengan kontrol positif, serta memiliki sifat fisika dan kimia yang baik.

\section{KESIMPULAN}

Berdasarkan hasil penelitian yang telah dilakukan maka dapat disimpulkan bahwa formulasi krim ekstrak metanol batang dan daun pacar air (Impatiens balsamina L.) dapat memberikan efek antijerawat paling besar yaitu krim dengan konsentrasi sebesar 20\% karena memiliki zona hambat terbesar dan berbedasignifikan dibandingkan dengan krim konsentrasi $10 \%$ dan $15 \%$. Krim yang dihasilkan memiliki sifat fisik krim homogen, tidak berminyak, mudah tercuci, memiliki daya sebar sebesar $10,18 \pm 0,285$ hingga $11,55 \pm 0,687 \mathrm{~cm}^{2}$, daya lekat sebesar 33,299 $\pm 2,821$ hingga $60 \pm 0$ menit, serta $\mathrm{pH}$ antara $6,07 \pm 0,058$ hingga $6,37 \pm 0,115$.

\section{DAFTAR PUSTAKA}

1. Williams C, Layton AM. Treatment of acne: an update Expert. Rev Dermatol. 2006; 1(3): 429-438.

2. Rivera AE. Acne scarring: a review and current treatment modalities. JAm Acad Dermatol.2008; 59: 659676.

3. Kurokawa I, Danby FW, Ju Q, Wang X, Xiang LF, Xia L, Chen W, Nagy I, Picardo M, Suh DH, Ganceviciene R, Schagen S, Tsatsou F, Zouboulis CC. New developments in our understanding of acne pathogenesis and treatment. Exp Dermatol.2009; 18: 821-832.

4. Olutunmbi Y, Paley K, English JC. Adolescent Female Acne: Etiology and Management. J Pediatr Adolesc Gynecol. 2008; 20(4): 171-176.

5. Gollnick H, Krautheim A. Topical treatment in acne: Current status and future aspects. Dermatol.2003; 206(1): 29- 36.

6. Ramos-e-Silva M, Coelho Carneiro SC. Acne Vulgaris: Review and Guidelines. Dermatol Nurs. 2009; 21(2): 63-68.

7. Auffret N. Acne today. What's new?. Presse Med.2000; 29(19): 10911097.

8. Amit G, Ashawat M.S, Shailendra S, Swarnlata S. Phyrosome: a novel approach towards functional cosmetics.J Plant Sci. 2007; 26: 644649. 
9. Coates P, Vyakmam S, Eady EA, et al. Prevalence of antibiotic-resistant propionibacteria on the skin of acne patients: 10-year surveillance data and snapshot distribution study. $\mathrm{Br} \mathbf{J}$ Dermatol. 2002; 146 (5): 840-848.

10. Ashawat MS, Amit G, Shailendra S, Swarnlata S. Role of highly specific and complex molecules in skin care. Int J Cancer Res. 2007; 3(4): 191195.

11. Wang YC, Li WY, Wu DC, Wang JJ, Wu CH, Liao JJ, Lin CK. In Vitro Activity of 2-methoxy-1,4naphthoquinone and Stigmasta-7,22 diene-3 $\beta$-ol from Impatiens balsamina L. against Multiple Antibiotic-Resistant Helicobacter pylori. Hindawi Publishing Corporation.2009. 1-8.

12. Buszello K, Muller BW. Emulsion as drug delivery systems. In Pharmaceutical Emulsions and Suspensions, Vol. 105, ed. Nielloud F and Marti-Mestres G. New York: Marcel Dekker, Inc. 2000. Hal 191.

13. Kuswahyuning R, Saifullah. Teknologi dan formulasi sediaan semipadat. Yogyakarta: Laboratorium Teknologi Farmasi Fakultas Farmasi UGM. 2008. Hal 74.

14. Clinical and Laboratory Standards Institute. Performance standards for antimicrobial disk susceptibility tests. Approved standard M2-A9. CLSI, Wayne, PA. 2006.

15. Departemen Kesehatan Republik Indonesia. Farmakope Indonesia, edisi keempat. Jakarta: Direktorat Jenderal Pengawasan Obat dan Makanan. 1995.

16. Michael and Ash I. A Formulary of Cosmetic Preparation. Chemical Publishing Co., New York. 1977.

17. Vats A, Sharma P. Formulation and Evaluation of Topical Anti Acne Formulation of Coriander Oil. Inter. J. Pharm. Sci. Res. 2012; 2(3): 6166.
18. Lim YH, Kim I.H, dan Seo JJ. In vitro activity of kaempferol isolated from the Impatiens balsamina alone and in combination with erythromycin or clindamycin against Propionibacterium acnes. J Microbiol. 2007; 45: 473-477.

19. Cowan MM. Plant Products as Antimicrobial Agents. Clin Microbiol Rev. 1999; 12 (4): 564582.

20. Handali S, Hosseini $H$, Ameri A, Moghimipour E. Formulation and evaluation of an antibacterial cream from Oxalis corniculata aqueous extract. Jundishapur J Microbiol. 2011; 4(4): 255-260.

21. Nishihata $T$, et al. Percutaneous absorption of diclofenac in rats and humans: aqueous gel formulation. Int J Pharm Pharmacol. 1998; 50: 413.

22. Ueda CT, et al. Topical and Transdermal Drug Products. Pharmacopeial Forum. 2009; 35(3): 750-764.

23. Swastika A, Mufrod, Purwanto. Aktivitas antioksidan krim ekstrak sari tomat (Solanum lycopersicum L.). Trad. Med. J. 2013; 18(3): 132140.

24. Lucero MJ, Vigo J, Leon MJ. A study of shear and compression deformations on hydrophylic gels of tretionin. Int J Pharm. 1994; 106: 125-133.

25. Asbill CS, Michniak BB. Percutaneous penetration enhancers: local versus transdermal activity. Pharmaceutical Science and Technology Today. 2000; 3(1): 3641.

26. Saifullah STN. Teknologi dan Formulasi Sediaan Semipadat. Yogyakarta: Laboratorium Teknologi Farmasi Fakultas Farmasi Universitas Gajah Mada. 2008. Hal 1-3. 
27. USP. The Official Compendia of Standard, First Annual Asian edition. 2002. Hal 554.
28. Anggraeni, Deni, Masril Malik dan Maria Susiladewi. Formulasi Krim Serbuk Getah Buah Pepaya (Carica papaya L) Sebagai Anti Jerawat. Semarang: Universitas Wahid Hasyim. [Publikasi Ilmiah]. 2006. 